BOTANICA

ISSN 2538-8657

2020, 26(2): 126-137

\title{
CHARA BALTICA (CHAROPHYCEAE, CHARALES) FROM THE BLACK SEA REGION AND TAXONOMIC IMPLICATIONS OF EXTRASTIPULODES
}

\author{
Roman Romanov ${ }^{1,2 *}$, Daria Korolesova ${ }^{3}$, Dmitry Afanasyev ${ }^{4}$, Liubov ZhaKova $^{5}$ \\ ${ }^{1}$ Komarov Botanical Institute of the Russian Academy of Sciences, Prof. Popov Str. 2, 197376 St Petersburg, \\ Russia \\ ${ }^{2}$ Institute for Water and Environmental Problems, Siberian Branch of the Russian Academy of Sciences, Molo- \\ dezhnaya Str. 1, 656038 Barnaul, Russia \\ ${ }^{3}$ Black Sea Biosphere Reserve of the National Academy of Sciences of Ukraine, Lermontov Str. 1, 75600 Gola \\ Prystan, Ukraine \\ ${ }^{4}$ Azov-Black Sea Branch of the Russian Research Institute of Fisheries and Oceanography, Beregovaja Str. 21b, \\ 344002 Rostov-na-Donu, Russia \\ ${ }^{5}$ Zoological Institute of the Russian Academy of Sciences, University Embankment 1, 199034 St Petersburg, \\ Russia \\ *Corresponding author. E-mail: romanov_r_e@ngs.ru
}

\begin{abstract}
Romanov R., Korolesova D., Afanasyev D., Zhakova L., 2020: Chara baltica (Charophyceae, Charales) from the Black Sea Region and taxonomic implications of extrastipulodes. - Botanica, 26(2): 126-137.

Chara baltica (Hartm.) Bruz. was found in the bays of the northern part of the Black Sea as a result of our joint efforts for clarification of some charophyte species from the region. The species was reported new to Ukraine. This is the first reliable record of this species in the Black Sea Region and Russia. In the studied populations, C. baltica had a variable arrangement of stipulodes because of the presence of extrastipulodes as a common trait. The morphology of the specimens studied may suggest a possible explanation of old uncheckable regional records of $C$. horrida Wahlst., species known from the Baltic Sea only. The worldwide range of $C$. baltica was summarised with a map according to the published records, GBIF data and some checked specimens. It highlighted the records, which need to be confirmed. The presence of extrastipulodes in the specimen studied, as well as the indication and illustration of some species of charophytes, allowed to suggest several additions to the terminology of charophyte morphology useful for further studies. Their application was demonstrated with the specimens studied and the illustrations published elsewhere.
\end{abstract}

Keywords: Black Sea, Chara baltica, Characeae, charophytes, distribution, stipulodes.

\section{INTRODUCTION}

The charophytes are commonly easily recognisable group, but some groups of the species resemble a "nightmare" in species delineation. The subsection Hartmania of Chara is one of the best examples of this ongoing taxonomic problem (URBANIAK, 2010; Schneider et al., 2015; Arbeitsgruppe Characeen Deutschlands, 2016; Urbaniak \& KwiatKowski, 2019). The noticeable regional differences in the taxonomy of the group, especially in the case of old published records can be overcome with the study of collections or new sampling. The continuous efforts of the authors to clarify as far as possible some records of charophyte species from the Black Sea resulted in the first reliable record of Chara baltica (Hartm.) Bruz. for the region and highlighted some taxonomic aspects associated with the formation of extrastipulodes by different species of Chara. 


\section{MATERIALS AND METHODS}

The specimens were collected during continuous monitoring of plant communities in the bays of the Black Sea in 2015-2016. The vouchers pressed and fixed in $4 \%$ formalin were deposited at the Komarov Botanical Institute (LE) of the Russian Academy of Sciences (St Petersburg, Russia). The collections of herbaria B, BCN, COI, H, L, LE, LISU, MA, W (the acronyms of the herbaria after THIERs (2020)) were studied in search of Chara baltica and C. horrida Wahlst. from the Black Sea and the neighbouring regions, as well as for the comparison with new collections of the species and clarification of their distribution. The photos of specimens stored at LE were taken using a Carl Zeiss Stereo Discovery V12 stereomicroscope equipped with an AxioCam MRs-5 digital camera. The map of records was made using SimpleMappr (http://www.simplemappr.net) based on cleaned GBIF records (GBIF.org, 2020), published data and some specimens, checked in the collections studied. It's impossible to include a complete bibliography of all records of $C$. baltica, therefore, we cited mostly relevant references having exact species localities and covering all distribution regions and records, omitting sources with repeating data.

\section{RESULTS AND DISCUSSION}

\section{Chara baltica in the Black Sea}

List of the specimens studied (Figs 1A-I, 2).

UKRAINE: 1. The Sea of Azov, Utlyutzkiy Liman, together with Chara aspera Willd., 24 August 1930, A.F. Zubovskiy (LE: A0000157); 2. The Sea of Azov, Kirillovskiy Bay [of] Utlyutzkiy Liman, near the northern coast of Fedotova Split at the meridian of Pereboynoe, stands, 13 July 1939, A.I. Proshkina (LE: A0000166); 3. Kherson Okrug (formerly Dneprovsky Uezd of Tavricheskaya Gubernia), Yagorlytskiy Bay of the Black Sea, between Kinburn Split and Island Dolgiy, 9 September 1926, A. Poretzky (LE: A0000167-A0000170). 4. The north-western part of the Black Sea, [Kherson Oblast], Tendrivska Bay [or Gulf of Tendra, the territory of the Black Sea Biosphere Reserve], in front of [split Bili] Kuchuhury, at a depth of $2.3 \mathrm{~m}$, on silt, 2 August 1937, I.I. Pohrebniak (LE: A0000158); 5. Tendrivska Bay, near [split Bili] Kuchuhury, at a depth of 7 ft. [2.1 m], 2 August 1937, I.I. Pohrebniak (LE: A0000159); 6. Tendrivska Bay, near island Orlov, at a depth of $0.5 \mathrm{~m}$, on silt and sand, 3 August 1937, I.I. Pohrebniak (LE: A0000160); 7-9. Kherson Oblast, Tendrivska Bay, the Black Sea Biosphere Reserve: 7. $46.186465^{\circ} \mathrm{N}, 31.98598667^{\circ} \mathrm{E}$, at a depth of $1.3 \mathrm{~m}$, on silty sand, 18 August 2015, D.D. Korolesova (LE: A0000161); 8. 46.22187167 $\mathrm{N}, 31.73646333^{\circ} \mathrm{E}$, together with Chara canescens Loisel. (female plants) and Lamprothamnium papulosum (Wallr.) J.Groves, 19 August 2015, D.D. Korolesova (LE: A0000162); 9. 46.227278 ${ }^{\circ}$, $32.063738^{\circ} \mathrm{E}$, at a depth of $1.1 \mathrm{~m}$, on silty sand, together with $C$. canescens (female plants), 19 August 2015, D.D. Korolesova (LE: A0000163). RUSSIA: 10, 11. Krasnodar Krai, Taman Bay, settlement of Sennoy [Sennaya]: 10 . at a depth of $0-0.5 \mathrm{~m}, 17 \mathrm{Oc}-$ tober 2015, D.F. Afanasyev (LE: A0000164); 11. at a depth of $1 \mathrm{~m}$, on silty-sandy ground, 17 October 2015, D.F. Afanasyev (LE: A0000165).

The habit and morphological traits of the specimens studied are in a good agreement with descriptions and illustrations of Chara baltica from the Baltic Sea (Schubert \& Blindow, 2003; UrbaniaK \& GąbKa, 2014; Arbeitsgruppe Characeen DeutSCHLANDS, 2016; URBANIAK \& KWIATKOWSKi, 2019) as well as with specimens checked (LE) except for extrastipulodes (Fig. 2) rarely noted in descriptions although traceable at some illustrations (see below). The plants are mostly sterile, and only some of them from the Utlyutzkiy Liman are fertile; no ripe oospores are available.

Chara baltica is a species record new to Ukraine and first reliable record to Russia and the Black Sea. The earlier reported record from small water bodies in inland brackish minerotrophic fen in Pskov Region of Russia belongs to C. papillosa Kütz. (EFimov et al., 2016; LE!).

According to the specimens studied, we can conclude that $C$. baltica still grows in the North Black Sea Region, at least in the same bay. However, the recent apparent decline of charophyte abundance has been found (Korolesova, 2015). By the mid-1990s, the stands of Chara referred to C. papillosa (as C. aculeolata Kütz. sensu Hollerb. et Krass.) had high biomass values in the bays and limans of the North Black Sea Region. They formed dense cover at the depths of $0.9-2.1 \mathrm{~m}$ on silt and silty sand at nearshores of 


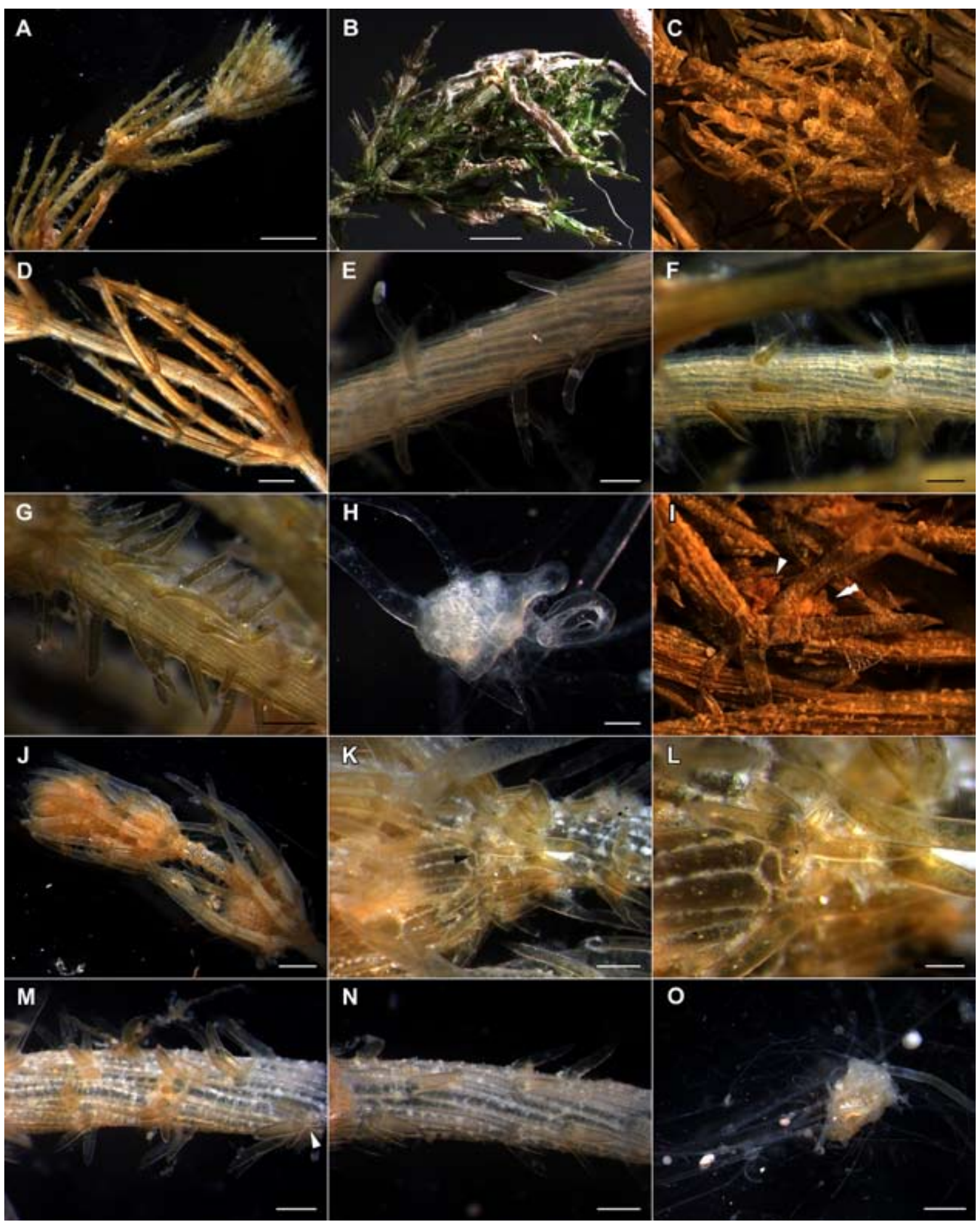

Fig. 1. Chara baltica (A-I) and C. papillosa (J-O) from the north of the Black Sea Region (LE). A, B, J - apical parts of plants; C, D - whorls of branchlets; E-G, M, N - tylacanthous stem cortex with solitary (E-G) or clustered spine cell (M, N); $\mathrm{H}, \mathrm{O}$ - nodal bulbils; I - conjoined gametangia (arrowhead - antheridium, double arrowhead - oogonium; a triangular shield of antheridium is visible below); $\mathrm{K}$ - whorl of stipulodes with triple extrastipulodes (arrowhead); $\mathrm{L}$ - triple extrastipulodes; $\mathrm{M}$ - stem cortex with clustered spine cells, up to four together (arrowhead). Scale: A -3 mm; B, D - $1 \mathrm{~mm}$; E, F - $0.3 \mathrm{~mm}$; G, $\mathrm{H}, \mathrm{K}, \mathrm{M}, \mathrm{N}-0.5 \mathrm{~mm} ; \mathrm{J}, \mathrm{O}-2 \mathrm{~mm}$; L $-0.2 \mathrm{~mm}$. All photos by R. Romanov 
Tendrivska, Yahorlytska, Dzharylgatska, Karkinitska bays. The abrupt decrease of the area occupied with Chara stands was found by the end of 1990s. For example, it reduced from more than $100 \mathrm{~km}^{2}$ to ca. $20 \mathrm{~km}^{2}$ in Tendrivska Bay in 2015-2016. The actual average biomass of Chara stands was 485.28 $\pm 221.17 \mathrm{~g} \mathrm{~m}^{-2}$ (Korolesova, 2015, 2017; Korole-
SOVA, unpubl. data), being by one order of magnitude lower than in the 1960s (PohrebNiaK \& OstrovchuK, 1973 ) and even in the early 1990s (ERYOMENKo \& Minicheva, 1992; TKachenko \& Maslov, 2002). The charophytes decreased due to the decrease of river irrigation drain as well as under eutrophication. The recent recovery of charophyte abundance has
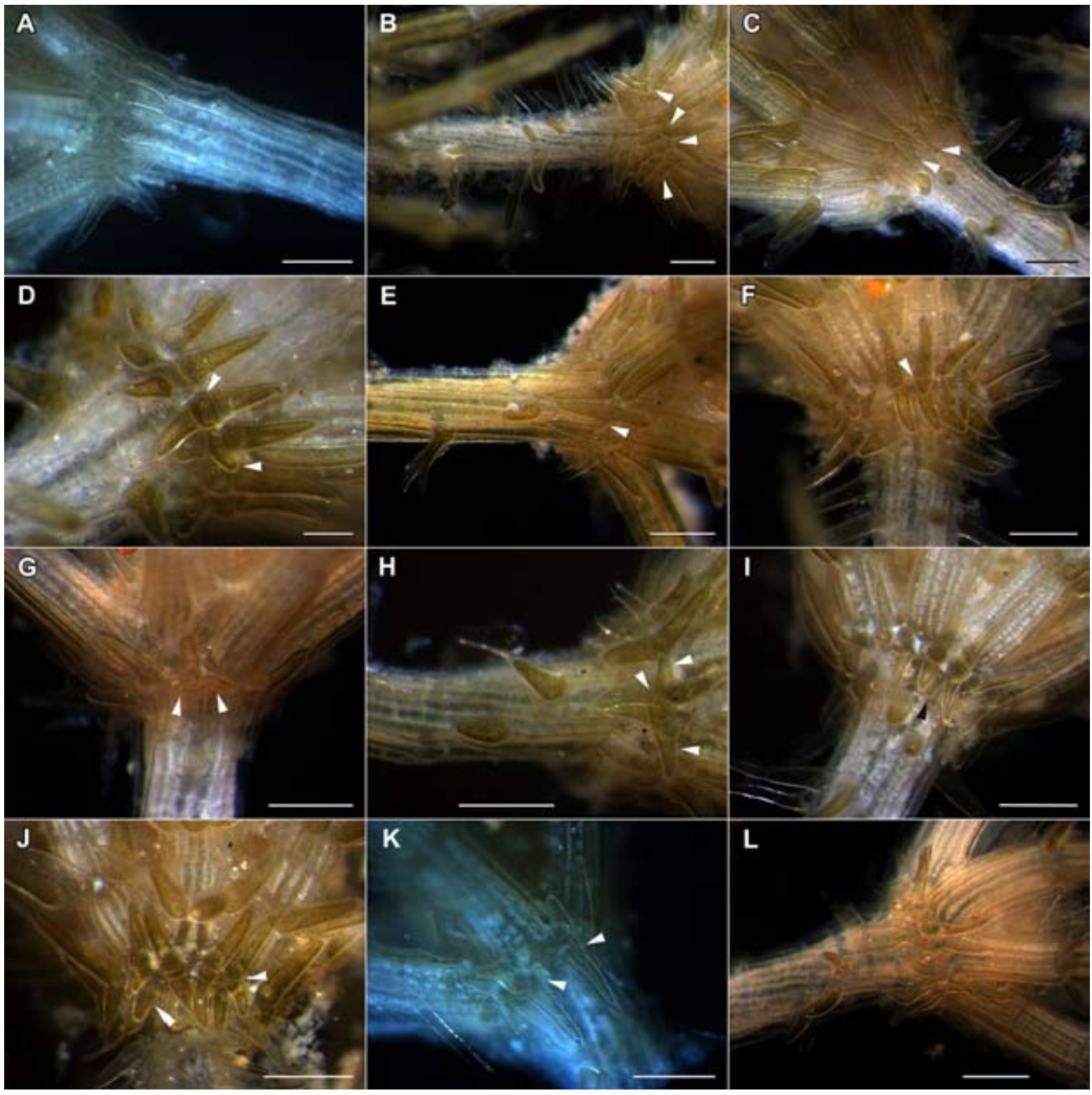

Fig. 2. Different patterns of stipulode whorl arrangement of Chara baltica from the North Black Sea Region (LE) A - diplostephanous whorl without extrastipulodes; B, C, F, I - diplo-triplostephanous whorls with conical or elongated central solitary extrastipulodes (arrowheads); D, E - triplostephanous whorl with papillate or conical central solitary extrastipulodes (arrowheads); G, H - diplo-triplostephanous whorls with conical lateral geminate extrastipulodes; J - diplo-triplostephanous whorl with vertical pair of extrastipulodes (left arrowhead) and conical central solitary extrastipulodes (right arrowhead); K - whorl with short lateral geminate (left arrowhead) and conical central solitary extrastipulodes (right arrowhead); L - flexuous stipulodes. Scale: D $-0.2 \mathrm{~mm}$, others $-0.5 \mathrm{~mm})$. All photos by R. Romanov 
not been found despite the evident reduction in human impact in the bays of the North-West Black Sea Region. The plants from Dzharylgatska Bay posted at the Ukrainian Biodiversity Information Network as Lamprothamnium papulosum (KALASHNIK, 2020) seem to belong to $C$. baltica, too.

We are expecting the recent occurrence of the species in Russia in the eastern part of Taman Bay near the settlements of Sennoy and Yubileiniy, and in Dinskoy Bay as well as along the southern coast of the Chushka Split, because the stands of charophytes similar by habit with Chara baltica are known from these areas at the depths of $0-3 \mathrm{~m}$ on sandy and silty bottom (AfanAsyev, unpubl. data). The area where charophyte stands still occur is not precisely known, but it definitely doesn't exceed $50 \mathrm{~km}^{2}$ and is currently undergoing intensive economic development. The decrease of natural habitat area, its fragmentation as a result of human activity, i.e. recreation, eutrophication and technogenic pollution, can be recognised as main threatening factors for C. baltica in Russia. Therefore, it is recommended to include this species into the Red Data Books of Ukraine, Russian Federation and Krasnodar Region.

According to the morphology of the specimens studied, i.e. presence of extrastipulodes, we can suggest some revision for existing records of Chara horrida in the Black Sea Region. Chara horrida can be referred to as a species of lagoon, known only from the Baltic Sea. Still, some old records outside of this region are known (Arbeitsgruppe Characeen DeutSCHLANDS, 2016), in particular one from water body associated with hot spring at the Római Baths in Budapest (FILARSZKY, 1893), which can be recognised as very improbable. Its recollection is impossible because of the severe transformation of the environment and disappearing of the water bodies (pers. comment by Attila Mesterhazy). Still, its voucher stored in HNHM can be restudied. Two localities are known from the Black Sea Region (PoDLESSKY, 1935; Pohrebniak, 1955), i.e. Beikushskyi or Bejkús'kyi Liman $\left(46^{\circ} 38^{\prime} 00^{\prime \prime} \mathrm{N}, 31^{\circ} 27^{\prime} 54^{\prime \prime} \mathrm{E}\right)$ and the Berezan Estuary, or Berezanskyi Liman $\left(46^{\circ} 42^{\prime} \mathrm{N}, 31^{\circ} 30^{\prime} \mathrm{E}\right)$ at Mykolaiv Oblast of Ukraine.

The species concept of Chara horrida clarified after these records (KRAUSE, 1997; SCHUBERT \& BLINDOw, 2004) seems to be not utterly coincident in details with manuals by W. Migula and A. Braun used by PodLessky (1935) for charophyte identification. Therefore, the species records published before the detailed description of $C$. horrida need to be checked, especially if they are extraordinary from the species distribution area. The morphology of the specimens studied by us allows suggesting that these unvouchered records (Podlessky, 1935; PohrebnIAK, 1955) could be actually based on specimens of C. baltica or C. papillosa (Figs 1,2). There are no new records of $C$. baltica and $C$. horrida from the region, but $C$. papillosa (as $C$. intermedia A. Braun ex A. Braun, Rabenh. et Stizenb.) is known there from the same habitats (Borisova et al., 2016). The similar situation can be noted for old unconfirmed record of C. baltica without exact locality in reed beds of the Danube Delta in Romania (Prodan, 1923; ArdeLEAN et al., 1967, cit. in: CARAUS, 2017). Notably, this species has not been found by V. Ionescu-Tुeculescu during their intensive research of charophytes in the Danube Delta. The search of Romanian specimens of C. baltica in the collection stored in $\mathrm{W}$ and elsewhere by the first author was not successful. Possibly this record was based on a specimen of C. globata Mig., a species occurring in coastal lakes of the region (RoMANOV, 2019).

The results of our study point towards checking of the collections from the Black Sea, the Sea of Azov and Lake Syvash, because Chara papillosa Kütz. (known from these regions as $C$. aculeolata sensu Hollerb. et Krass. or $C$. intermedia), i.e. species easily confusing with $C$. baltica, is the most frequently reported species in lagoons and bays of the regions listed (Gromov, 2012; Borisova et al., 2016). Therefore, restudy of the available specimens, and future field studies are essential for clarification of the past and actual distribution of C. baltica and C. papillosa in this region. Sometimes their delineation is tricky. Therefore, we illustrated C. papillosa from coastal water body of Tendrivska Bay collected at the same period (18 August 2016) at $46.1404^{\circ} \mathrm{N}, 32.23406^{\circ} \mathrm{E}$ by D.D. Korolesova (LE: A0000167; Fig. 1J-O). The key traits useful for species identification have been described elsewhere (Krause, 1997; Schubert \& Blindow, 2003; UrbaniaK \& GąBKa, 2014; Mouronval et al., 2015; Arbeitsgruppe CharaceEn DeutschLANDS, 2016), but for our case, we can note usually clustered spine cells (up to four!) and somewhat encrustation for C. papillosa as the most important traits 
for differentiation with mainly solitary spine cells and absence of incrustation of $C$. baltica (cf. Figs $1 \mathrm{~A}-\mathrm{G}$ and $\mathrm{J}-\mathrm{N}$ ). The extrastipulodes were found in plants of both species. The lateral geminate stipulodes have been found in C. papillosa from brackish fen in Pskov Oblast, too (Romanov \& ZhaKova, unpubl.).

\section{Worldwide distribution}

Chara baltica is mostly known from coastal regions of European countries bordering the Baltic Sea (except for Russia; Krause, 1997; Schubert \& BlinDOW, 2003; URBANIAK, 2010; TORN et al., 2015; URBANiaK \& Combik, 2013; Arbeitsgruppe Characeen Deutschlands, 2016; Urbaniak \& Sakayama, 2017; SinKEVIČIENĖ et al., 2017; URBANIAK \& KWIATKOWSKI, 2019) and the Atlantic Ocean (except for Iceland and Portugal; Braun \& Nordstedt, 1883; Corillion, 1957; Compère, 1992; Stewart \& ChurCh, 1992; Langangen \& Åsen, 1996; Roden, 1999; Langangen et al., 2001; NDFF, 2020; IrishLagoons.COM, 2020) as well as from the Mediterranean: Spain (CoRILLION, 1962; Tomas, 1980; Margalef-Mir, cit. in: AbOal, 1986; Krause, 1997; Cirujano et al., 2007; RodRIGO \& Alonso-Guillén, 2016), France (Mouronval et al., 2015), Italy (BECKER, 2019; Romanov et al., 2019), Slovenia (Firbas \& Al-SABAti, 1995), Albania (Zeneli \& Kashta, 2016), Greece (without exact locality; SchNeIDER et al., 2015), and North Africa (Corillion \& Guerlesquin, 1971; Compère, 1986; Muller et al., 2017). The plants from the Med- iterranean can belong to another species (BLINDOw \& ERICHSEN, 2010). The records of C. baltica from Ireland have not been confirmed (IRISHLaGoons. COM, 2020), but the occurrence of the species there seems to be possible.

Few records of Chara baltica outside of its main distribution area are known from the coastal brackish lake in Greenland (LANGangen \& BenNiKe, 1997), shallow semi-permanent ponds with clear water at the coast of Persian Gulf in Iran (FLOR-ARNAU, 2014), shallow brackish lakes associated with the River Ili and Lake Balkhash in Kazakhstan (without exact locality; Kostin, 1987) and pond in Central China (LinG, 1985; as C. baltica var. borealis Y.J. Ling). All records from Asia need to be confirmed. Chinese plants possibly better to designate as another species, e.g. C. papillosa. They need to be restudied, because their drawings and descriptions are insufficient for further clarification. Voucher or any other specimens of $C$. baltica from Kazakhstan are still not found during continuous efforts for revision of Kazakhstan charophytes by the first author.

The records of Chara baltica do exist for South America. Still, most of them, e.g. from Lake Titicaca, belong to C. andina (A.Braun) R.D. Wood, usually reported as $C$. baltica var. andina A. Braun (Blindow et al., 2018). Most probably a single record from Brazil is based on Chara from subsection Willdenowia, one of the most common species group in the region (RIBEIRO et al., 2018) and sometimes having somewhat superfi-

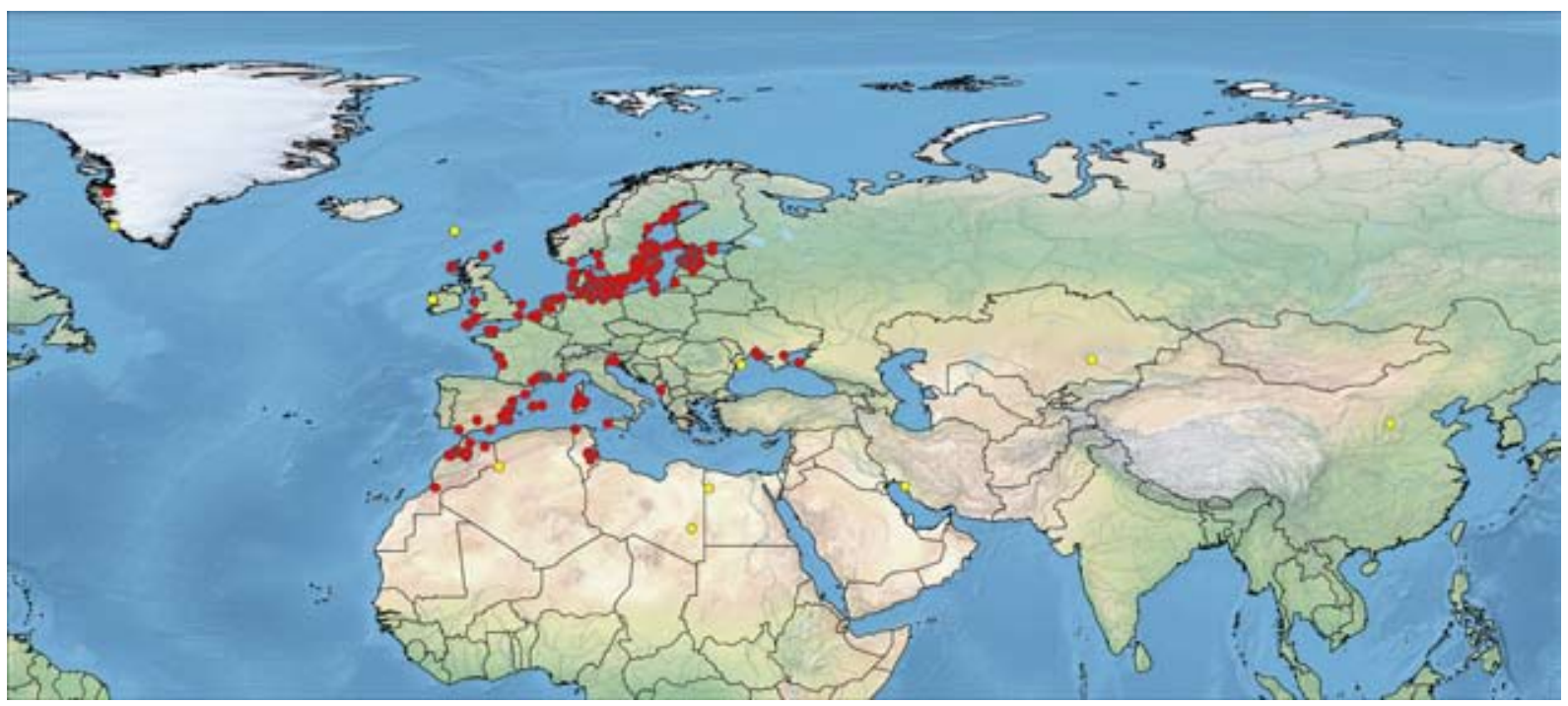

Fig. 3. Worldwide distribution of Chara baltica according to the records from GBIF, publications and studied specimens. Red dots - reliable records, yellow dots - records for future confirmation 
cial similarity with C. baltica var. liljebaldii (Wallm.) Hasslow, the name applied for Brazilian specimen by Hasslow (1934). The restudy of its voucher is desirable. Chara baltica has been reported from Argentina (GARCíA, 1993). This record seems to belong to the taxon (possibly C. andina) different from C. baltica, because dimensions of its gametangia and oospores are smaller than known for the species from Europe (Arbeitsgruppe Characeen Deutschlands, 2016).

Therefore, worldwide distribution area of Chara baltica can be summarised with a map (Fig. 3) according to the references listed above, GBIF data (GBIF.ORG, 2020) and some checked specimens (LE, $\mathrm{MA}, \mathrm{W})$. It allowed achieving better visualisation of species records than known before (CoRILLION, 1957; Corillion \& Guerlesquin, 1971; García, 1993; ARBeitsgruppe Characeen Deutschlands, 2016; Kor$\mathrm{sCH}, 2018$ ) and suggesting several records outside of the main distribution area for further confirmation.

\section{Taxonomic implications of extrastipulodes}

The stipulode arrangement traits, i.e. common presence of extrastipulodes found in the plants of C. baltica and C. papillosa from the Black Sea Region, need to be discussed in the perspective of possible taxonomic implications and future morphological studies. For a long time, typical variants of stipulode arrangement have been recognised - haplostephanous $v s$. diplostephanous and unistipulate $v s$. bistipulate depending on the number of rows and number of stipulodes per branchlet (WOOD \& IMAHORI, 1965). The diplostephanous unistipulate branchlet seems to be unknown. Therefore, the diplostephanous bistipulate stipulodes mean the presence of four stipulodes, or in other words, two vertical pairs, each originating from own initial cell, per branchlet; and only three variants of stipulode arrangement can be suggested. Some deviations from this scheme do occur, e.g. when some or all stipulodes are absent in lower row, or both variants of stipulode number per branchlet present within the same plant or even in the same whorl (WoOD \& IMAHORI, 1965).

The formation of extrastipulodes by some charophyte species is the further complication of this scheme. We found some variants of their arrangement in the specimens listed above allowing suggesting some additions to terminology for charophyte morphology. The formation of extrastipulodes can be accommodated within the standard scheme for bistipulate stipulodes description as recognising of variants of diplo-triplostephanous and triplostephanous stipulodes. The first case means the presence of extrastipulodes not in all pairs of the main stipulodes. We suggest maintaining the term "bistipulate" for all these cases, because all extrastipulodes originated from the initial cell of the main stipulodes. The number of these initial cells and groups of stipulodes deriving from them, i.e. having a common origin, in any case, is two per branchlet.

Three types of diplo-triplostephanous and triplostephanous bistipulate stipulodes are available. 1 . The stipulodes form a third row consisting of cells easily spotted between rows of the main stipulodes, i.e. one per vertical pair of the main stipulodes (Fig. 2B, C, F, I). The extrastipulodes can be rudimentary or elongate and acuminate. They can be called central solitary extrastipulodes. 2. The extrastipulodes are forming from both sides of each pair of stipulodes (Fig. 2G, H). In this case, they can be called lateral geminate extrastipulodes. 3 . The combination of central solitary and lateral geminate extrastipulodes can occur in the same pair of the main stipulodes (Figs $1 \mathrm{~K}, \mathrm{~L}, 2 \mathrm{~K}$ ). This case can be tentatively named triple extrastipulodes.

Besides this pattern, extrastipulodes can be formed as vertical pairs of cells between main stipulodes. The term "multistipulate stipulodes" can be suggested for this case. This pattern is recognisable in the photo of $C$. horrida (http://www.schattenblick. de/infopool/natur/botanik/nbom0056/2-nbom0056chara_horrida_stipul_gustav_johansson_print.jpg). Also, it is complicated with the presence of single central stipulode at some vertical pairs of the main stipulodes. It should be noted that illustrated part has tylacanthous stem cortex; therefore, the plant does not fit the recent concept of $C$. horrida, described as having isostichous or slightly aulacanthous stem cortex (Schubert \& Blindow, 2003; Arbeitsgruppe Characeen Deutschlands, 2016).

Chara horrida is the remarkable exclusion standing apart even from all these deviations. It produces so many stipulodes that their primary number, i.e. four per branchlet, is significantly increased. Stipulodes are described as huddled together without a special order (KRAUSE, 1997) or arranged in more than two rows (Schubert \& Blindow, 2003), or two compressed 
rows (Arbeitsgruppe Characeen Deutschlands, 2016). Anyway, it has numerous extrastipulodes, but their arrangement pattern is tricky to describe, because available drawings are insufficient for this and available photos are few and are not enough to describe it correctly (cf. http://www.biopix.com/zoom. aspx?photoid=125522, http://www.schattenblick.de/ infopool/natur/botanik/nbom0056.html, http://www. muutoslehti.fi/wp-content/uploads/2016/10/Chara horrida_BothnianSea_Isokari_24082016_Metsahallitus_Heidi_Arponen_P8270207.jpg). Therefore, the details of stipulode arrangement in the case of C. horrida seem to be missing and will be a real challenge in the further studies of its fresh specimens.

Besides of Chara horrida having numerous extrastipulodes as a typical species trait as well as C. baltica and C. papillosa from the Black Sea Region studied by us, the formation of extrastipulodes can be traced for another species from four subsections. Except $C$. horrida, usually, they are somewhat or shorter than the main stipulodes, but rarely the extrastipulode is nearly equal with neighbouring stipulode in the lowest row. The whorl of stipulodes with additional row was illustrated for the subsection Chara, i.e. C. tomentosa L. from Central Europe (as C. ceratophylla Wallr., Migula, 1897: Fig. 14). MiguLA (1897) named them "dreifacher Stipularkranz" and noted that this stipulode arrangement is sometimes occurring, but could be incomplete and does not form in juvenile whorls. It has been occurring in different but not in all plants from the same locality (Migula, 1897: 390). We suggest naming this variant of stipulode arrangement as triplostephanous, with rudimentary central solitary extrastipulodes. They are shown at each pair of the main stipulodes (Migula, 1897: Fig. 14). Another variant has been illustrated for Polish plant C. tomentosa (URBANIAK \& GĄBKA, 2014: 22, Fig. 5.5). It can be assigned to diplostephanous stipulodes with the presence of central solitary elongate extrastipulode, because all stipulodes illustrated are visible. The extrastipulode is recognisable for sure in only one pair of the main stipulodes.

In section Desvauxia, the extrastipulodes were illustrated for Chara canescens from Great Britain (GUIRY \& GuIRY, 2020: image 21317). This case can be named diplo-triplostephanous stipulodes with incomplete third row consisted of conical and elongate central solitary extrastipulodes, because nearly all stipulodes illustrated are visible in the photo. The extrastipulodes are recognisable for sure at least in several pairs of the main stipulodes.

In section Grovesia, Chara leptosperma A. Braun from Arizona has been illustrated and described as having extrastipulodes (TINDALL, 1966: Fig. 38). This case can be tentatively assigned to diplostephanous stipulodes with the frequent presence of central solitary or geminate elongate or short extrastipulodes. Chara strigosa A. Braun can form extrastipulodes at least in some Asian populations (as C. locuples Hollerb., Hollerbach \& Krassavina, 1983; Romanov et al., 2014); their arrangement needs to be studied in details. Chara curta Nolte ex Kütz. from NorthEast France has been illustrated with extrastipulodes (Bailly \& Schaefer, 2010: 54, Fig. 5). This variant can be assigned to diplo-triplostephanous with incomplete third row consisted of elongated lateral geminate extrastipulodes, because nearly all stipulodes are visible in the photo (BAILly \& SChaEfer, 2010: 54, Fig. 5). The extrastipulodes are recognisable for sure at least in two pairs of the main stipulodes. Moreover, the presence of the third extrastipulode can be suggested, but can't be recognised for sure. Another placement of extrastipulodes for the same species has been found in the plants from Mediterranean France (as C. aspera var. curta (Nolte ex Kütz.) A. Braun ex Leonh.; Mouronval et al., 2015: 83, Fig. 6). The extrastipulodes are named "stipulodes surnumeraires", and they occur in some of the plants studied (Mouronval et al., 2015: 83). This case can be tentatively assigned to diplo-triplostephanous with incomplete third row consisted of conical central solitary extrastipulodes, because it is not visible in the photo for all stipulodes illustrated (MourONVAL et al., 2015: p. 83, Fig. 6). The extrastipulodes are recognisable for sure at least in two pairs of the main stipulodes.

In subsection Hartmania, the extrastipulodes have been illustrated for Chara papillosa from Sweden (as C. aculeolata sensu auct. nonnul.; OLSEN, 1944: Fig. 18a). This variant can be named diplotriplostephanous stipulodes with few conical and elongate acuminate central solitary extrastipulodes. Another pattern with conical lateral geminate and central solitary extrastipulodes in the same pair of the main stipulodes was found for $C$. papillosa during this study (Fig. $1 \mathrm{~K}, \mathrm{~L}$ ). The case of C. subspinosa 
Rupr. from North-East France (as C. rudis A. Braun; BAILly \& SCHAEFER, 2010: 44, Fig. 5) can be assigned to diplostephanous with single elongate central solitary extrastipulode, because all stipulodes illustrated are visible. The extrastipulode is recognisable for sure in only one pair of the main stipulodes. Finally, the presence of extrastipulodes in C. baltica from the Baltic Sea Region is known and illustrated (SCHUBERT \& BLINDOw, 2003: 56, Fig. 4.3.2; the former drawing erroneously had been referred to $C$. baltica var. breviaculeata Kütz.; URBANIAK \& GĄBKA, 2014: 43, Plate 2, left lower photo; URBANIAK \& KWIATKOWSKI, 2019: Fig. 1). The first case possibly illustrates triplostephanous stipulodes with lateral geminate extrastipulodes and pairs of extrastipulodes between main stipulodes. The second case can be assigned to diplo-triplostephanous stipulodes with incomplete third row consisted of elongate central solitary extrastipulodes, because all stipulodes illustrated are visible in the photo (URBANIAK \& GĄBKA, 2014: 43, Plate 2, left lower photo), and extrastipulodes are recognisable for sure at least in two pairs of the main stipulodes.

This picture can be complicated with the formation of accessory short ecorticate branchlet with few nodes looking as apical part of a branchlet and originating below of the base of main branchlets, i.e. from typical stipulode place. It is known for C. horrida (Krause, 1997: Fig. 21D). It seems to be illustrated for C. baltica, too, with the photo taken from Scottish specimen (cf. GUIRY \& GUIRY, 2020: image 26434).

Therefore, the cases of extrastipulode development should be included in the descriptions of charophyte specimens for further clarification of the significance of this trait for species delimitations as well as for outlining of possible differences between populations of the same species. Evidently, at the moment, we can't estimate the right scale and taxonomic implications of this phenomenon.

\section{ACKNOWLEDGEMENTS}

We thank Irmgard Blindow and Nick Stewart for the confirmation of some specimens from the Black Sea and Pskov regions; Emile Nat, Adriana García, Dmitry Kapustin Valentyna Klymiuk and Jelena Blaženčić for their kind help with hardly accessible references; Attila Mesterhazy for the clarification of localities from Hungary; anonymous reviewers for their valuable suggestions. The curators of the herbaria listed above are kindly acknowledged for their encouragement and guidance. This work was supported by the Russian Foundation for Basic Research, project No. 20-04-00280, and partly by the project AAAA-A18-118022090078-2 of the Komarov Botanical Institute of the Russian Academy of Sciences and the state order for IWEP SB RAS according to the research project No. 0383-2016-0003, also by the National Academy of Sciences of Ukraine, research theme "Fundamentals of functioning and adaptation of natural complexes of the Black Sea Biosphere Reserve under the action of biotic and abiotic factors" (2012-2016, state registration No. 0112U000467).

\section{REFERENCES}

Aboal M., 1986: Aportación al conocimiento de las algas del SE deEspaña. I. Caráceas (Characeae). Anales Biología, Facultad Biología, Universidad de Murcia, 6: 7-17.

Arbeitsgruppe Characeen Deutschlands, 2016: Armleuchteralgen - Die Characeen Deutschlands. - Berlin, Heidelberg.

Ardelean I., Prunescu-Arion E., Banu C.A., Bănărescu P., Boisnard J., Brezeanu Gh., Buşniță Th., Enăceanu V., Maianu Al., Marinescu M., Mociorniță C., Obrejanu Gr., Oltean M., Popescu-Zeletin I., Rudescu L., StĂnescu Al.V., 1967: Limnologia sectorului românesc al Dunării. - Bucuresti.

Bailly G., Schaefer O., 2010: Guide illustré des Characées du nord-est de la France. - Besançon.

BeCKER R., 2019: The Characeae (Charales, Charophyceae) of Sardinia (Italy): habitats, distribution and conservation. - Webbia, 74(1): 83-101.

Blindow I., ERICHSEN I., 2010: Cross-fertilisation within the Chara baltica species complex. - Charophytes, 2(2): 59-65.

Blindow I., Marquardt R., Schories D., SchuBERT H., 2018: Charophyceae of Chile - taxonomy and distribution. Part 1. Subfamily Chareae. Nova Hedwigia, 107(1-2): 1-47.

Borisova O.V., Palamar-Mordvintseva G.M., TSARENKo P.M., 2016: Flora algarum Ucrainicae. Charophyta, 12(2). - Kyiv.

Braun A., Nordstedt C.F.O., 1883: Fragmente einer Monographie der Characeen von Hrn. A. Braun. 
nach den hinterlassenen Manuscripten A. Braun's herausgegeben von Hrn. Dr. Otto Nordstedt. Abhandlungen der Königlich Preussischen Akademie der Wissenschaften, 1882(1): 1-211.

CARAus I., 2017: Algae of Romania. A distributional checklist of actual algae. Version 2.4. - Studii si Cercetari Biologie, 7: 1-1002.

Cirujano S., García Murillo P., Meco A., FernánDEZ ZAMUdio R., 2007: Los carófitos ibéricos. Anales del Jardín Botánico, 64(1): 87-102.

Compère P., 1986: Algues recoltees par J. Leonard dans le desert de Libye. - Bulletin du Jardin Botanique National de Belgique / Bulletin van de National Plantentuin van België, 56(1/2): 9-50.

Compère P., 1992: Flore pratique des Algues d'eau douce de Belgique. Charophytes, 4. - Meise.

Corillion R., 1957: Les Charophycées de France et d'Europe Occidentale. - Bulletin de la Société. Scientifique de Bretagne, 32, hors ser. 1: 1-259; 2: 260-499.

Corillion R., 1962: Nouvelle contribution à l'étude des Charophycées de la peninsule ibérique et du Maroc occidental. - Bulletin de la Société Scientifique de Bretagne, 37: 65-80.

Corillion R., GuERLESQuin M., 1971: Notes phytogéographiques sur les Charophycées d'Egypte. - Revue Algologique, n.s., 10: 177-191.

Efimov P.G., Konechnaya G.Yu., Zhakova L.V., 2016: On the maritime elements in the Pskov Region flora. - Botaničeskij Žurnal, 101(8): 910 923.

ERyomenko T.I., Minicheva G.G., 1992: Strukturnofunkcionalnaja xarakteristika donnoj rastitelnosti Jagorlytskogo zaliva. - Prirodnye kompleksy Chernomorskogo gosudarstvennogo biosfernogo zapovednika: 44-48.

FilarszKY N., 1893: A Charafélék (Characeae L. Cl. Richard) különös tekintettel a magyarországi fajokra. - Budapest.

Firbas P., Al-Sabati K., 1995: Cytosystematic studies on the Charophyta in Slovenia. - Archives of Biological Sciences, 47(1-2): 49-58.

Flor-Arnau N., 2014: Diversitat, ecologia i usos en bioindicació d'algues caràcies i macròfits a la península Ibèrica. Tesi doctoral. - Barcelona.

García A., 1993: Chara baltica Bruzelius (Charophyta) en Argentina. - Candollea, 48: 287-303.

GBIF.ORG, 2020: Chara baltica GBIF Occurrence.
Download https://doi.org/10.15468/dl.uvtqv6 [Accessed 18 April 2020].

Gromov V.V., 2012: Aquatic and coastal vegetation of the northern and western coast of the Azov Sea. - Journal of Siberian Federal University, 2(5): 121-137.

Guiry M.D., Guiry G.M., 2020: AlgaeBase. Worldwide electronic publication, National University of Ireland, Galway. - http://www.algaebase.org [Accessed 24 April 2020].

HassLow O.J., 1934: Några characeer från Amerika. - Botaniska Notiser, 4: 346-348.

Hollerbach M.M., Krassavina L.K., 1983: Opredelitel presnovodnyx vodoroslej SSSR. Xarovye vodorosli - Charophyta, 14. - Leningrad.

IRISHLAGOONS.COM, 2020: Information on Lagoons in Ireland. - http://www.irishlagoons.com [Accessed 24 April 2020].

KaLASHNIK E., 2020: Lamprothamnium papulosum. Images ID \# 144697-144702. - UkrBIN: Ukrainian Biodiversity Information Network [public project \& web application]. UkrBIN, Database on Biodiversity Information. - http://www.ukrbin. com [Accessed 18 June, 2020].

Korolesova D.D., 2015: The biocoenoses of charophytes as an important element of coastal ecosystems (by the example of Tendrovsky and Yagorlytsky Bays of the Black Sea). - Odesa National University Herald. Geography and Geology, 20(1): 134-148. [In Russian].

Korolesova D.D., 2017: Current state of the macrophytobenthos in Tendrivska and Yagorlycka Bays of the Black Sea Biosphere Reserve. - Chornomorski Botanical Journal, 13(4): 457-467.

Korsch H., 2018: The worldwide range of the charophyte species native to Germany. - Rostocker Meeresbiologische Beiträge, 28: 45-96.

Kostin V.A., 1987: Materialy k izučeniju ecologii xarovyx vodoroslej vodoëmov Ili-Balxašskogo basseina. - Botaničeskie Materialy Gerbarija Instituta Botaniki Akademii Nauk Kazaxskoj SSR, 15: 128-133.

Krause W., 1997: Süßwasserflora von Mitteleuropa. Charales (Charophyceae), 18. - Jena.

Langangen A., Åsen P.A., 1996: Kransalgen Chara baltica Bruz. gjenfunnet i Gillsvannet i Kristiansand. - Blyttia, 54: 181-184.

Langangen A., Bennike O., 1997: Chara baltica 
found in Greenland. - Cryptogamie, Algologie, 18: 375-376.

Langangen A., GaArder G., Jordal J.B., 2001: Kransalgen grønnkrans Chara baltica Bruzelius funnet på Smøla i Møre og Romsdal. - Blyttia, 59: 101-103.

LiNG Y.J., 1985: Characeae of Shanxi. - Journal of Shanxi University (Nat.Sci.Ed.): 56-64.

Migula W., 1897: Unter Berücksichtigung aller Arten Europas. L. Rabenhorst - Kryptogamenflora von Deutschland, Oesterreich und der Schweiz.

2. Die Characeen Deutschlands, Oesterreichs und der Schweiz, 5. - Leipzig.

Mouronval J.B., Baudouin S., Borel N., SouliéMärsche I., Klesczewski M., Grillas P., 2015: Guide des Characées de France méditerranéenne. - Paris.

Muller S.D., Rhazi L., Soulie-Märsche I., Benslama M., Bottollier-Curtet M., Daoud-Bouattour A., De Belair G., Ghrabi-Gammar Z., Grillas P., Paradis L., Zouaïdia-Abdelkassa H., 2017: Diversity and distribution of Characeae in the Maghreb (Algeria, Morocco, Tunisia). Cryptogamie Algologie, 38(3): 201-251.

NDFF, 2020: NDFF Verspreidingsatlas. LIK Verspreidingsatlas Kranswieren. - https://www. verspreidingsatlas.n1/2110 [Accessed 24 April 2020].

Olsen S., 1944: Danish Charophyta. Chorological, ecological and biological investigations. - Det Kongelige Danske Videnskabernes Selskab, Biologiske Skrifter 3(1): 1-240, plates 1-2.

Podlessky V.I., 1935: The Charophyta of the SouthWestern part of the Ukraine. - Journal de l'Institut Botanique de l'Académie des Sciences D'Ukraine, 7(15): 65-69.

PohrebniaK I.I., 1955: Donnaja rastitelnost Berezanskogo limana. - Trudy Odesskogo Gosuniversiteta im. I.I. Mečnikova. Serija biologičeskix nauk, 145(7): 181-196.

Pohrebniak I.I., Ostrovchuk P.P., 1973: Fitocenozy mjagkix gruntov severo-zapadnoj časti Černogo morja. - Materialy Vsesojuznogo simpoziuma po izyčennosti Černogo i Sredizemnogo morej, ispolzovaniju i oxrane ix resursov, 3: 145-147.

Prodan I., 1923: Flora critică a Dobrogei. - Analele Dobrogei, 1923: 217-248.

Ribeira C. dos A., Ramos G.J.P., Bueno N.C., Pra-
Do J.F. , Moura C.W. do N., 2018: O gênero Chara (Charophyceae, Characeae) das Regiões Metropolitanas de Salvador e de Feira de Santana, Bahia, Brasil. - Rodriguésia, 69(4): 1987-2017.

Roden C.M., 1999: A survey of the flora and vegetation of sixteen Irish coastal lagoons. Part three of 1998 lagoon survey. - Dublin.

Rodrigo M.A., Alonso-Guillén J.L., 2016: The charophyte flora in a Ramsar Mediterranean wetland (Albufera de València Natural Park, Spain) during the period 2007-2010. - Botanica Serbica, 40(2): 205-215.

Romanov R., 2019: New interesting records of charophytes (Charales, Charophyceae) from Eurasia and Africa. - Webbia, 74(1): 159-166.

Romanov R.E., Chemeris E.V., Vishnyakov V.S., Chepinoga V.V., Azovskil M.G., Kuklin A.P., Timofeeva V.V., 2014: Chara strigosa (Streptophyta: Charales) in Russia. - Botaničeskij Žurnal, 99(10): 1148-1161.

Romanov R., Napolitano T., van de Weyer K., TroiA A., 2019: New records and observations to the Characean (Charales, Charophyceae) flora of Sicily (Italy). - Webbia, 74(1): 111-119.

Schneider S.C., Rodrigues A., Moe T.F., Ballot A., 2015: DNA barcoding the genus Chara: molecular evidence recovers fewer taxa than the classical morphological approach. - Journal of Phycology, 51(2), 367-380.

Schubert H., Blindow I. (eds), 2003: Charophytes of the Baltic Sea. - Ruggel.

SinkevičIenè Z., Bučas M., Ilginè R., Vaičıūtė D., Kataržytė M., Petkuviené J., 2017: Charophytes in the estuarine Curonian Lagoon: Have the changes in diversity, abundance and distribution occurred since the late 1940s? - Oceanological and Hydrobiological Studies, 46(2): 186-198.

Stewart N.F., ChURCh J.M., 1992: Red data books of Britain and Ireland: Stoneworts. - Peterborough.

Thiers B., 2020: Index herbariorum: A global directory of public herbaria and associated staff. New York Botanical Garden's Virtual Herbarium. -http://sweetgum.nybg.org/ih/ [continuously updated].

Tindall D.R., 1966: The systematics and ecology of the Characeae (Nitella and Chara) of southwestern United States and northern Mexico. PhD Dissertation. - Louisville. 
Tкаснеnкo F.P., Maslov I.I., 2002: Marine macrophytobenthos of Chernomorsky Biosphere Reservation. - Ecology of the Sea, 62: 34-40.

Tomas X., Lopez P., Margalef-Mir R., Comin F.A., 1980: Distribution and ecology of Compsopogon coeruleus (Balbis) Montagne (Rhodophyta, Bangiophycideae) in Eastern Spain. - Cryptogamie, Algologie, 1: 179-186.

Torn K., Kovtun-Kante A., Herküla K., Martin G., MäEMETS H., 2015. Distribution and predictive occurrence model of charophytes in Estonian waters. - Aquatic Botany, 120(A): 142-149.

URBANIAK J., 2010: Analysis of morphological characters of Chara baltica, C. hispida, C. horrida, and $C$. rudis from Europe. - Plant Systematics and Evolution, 286: 209-221.

Urbaniak J., Combik M., 2013: Genetic and morphological data fail to differentiate Chara intermedia from C. baltica, or C. polyacantha and C. rudis from C. hispida. - European Journal of Phycology, 48(3): 253-259.

Urbaniak J., GąBKa M., 2014: Polish charophytes. An illustrated guide to identification. - Wroclaw. Urbaniak J., Sakayama H., 2017: Taxonomical analysis of closely related species of Chara L. section Hartmania (Streptophyta: Charales) based on morphological and molecular data. - Fottea, Olomouc, 17(2): 222-239.

Urbaniak J., KwiatKowski P., 2019: Taxonomic studies on the Chara section Hartmania in Poland based on morphological and molecular data. - PhytoKeys, 135: 71-90.

Wood R.D., IMAHORi K., 1965: A revision of the Characeae, 1. - Weinheim.

Zeneli V., Kashta L., 2016: Some Charophyta (Charales) from coastal temporary ponds in Velipoja Area (North Albania). - Journal of Environmental Science and Engineering, B5: 69-77.

\title{
CHARA BALTICA (CHAROPHYCEAE, CHARALES) IŠ JUODOSIOS JŪROS REGIONO IR TAKSONOMINĖ PERTEKLINIỤ PRIDĖTINIỤ PRIELAPIŲ REIKŠMĖ
}

\author{
Roman Romanov, Daria Korolesova, Dmitry Afanasyev, Liubov Zhakova
}

\section{Santrauka}

Chara baltica (Hartm.) Bruz. buvo rasta Juodosios jūros šiaurinès dalies ịlankose, vykdant šio regiono maurabraginių rūšių tyrimus. Tai pirmas patikimas šios rūšies radavietès aptikimo ịrašas Juodosios jūros regione, Ukrainoje ir Rusijoje. Tirtose populiacijose C. baltica turejo skirtingą prielapių išsidèstymą, o pridètiniai prielapiai yra ịprastas maurabraginių požymis. Šiame darbe tirtų pavyzdžių morfologija yra svarbi identifikuojant kitą nepatikslintą rūšį, $C$. horrida Wahlst., kuri žinoma tik Baltijos jūros regione. Straipsnyje pateiktas apibendrintas $C$. baltica paplitimo pasaulyje žemèlapis, kuris sudarytas pagal paskelbtus įrašus, GBIF duomenis ir šiame darbe aprašytus pavyzdžius. Nustatyti pridètiniai prielapiai ir jų iliustracijos sudaro pagrindą patikslinti maurabraginių morfologijos aprašymą, kas turès reikšmès tolesniuose tyrimuose. 